\title{
The Effect of Market and Entrepreneurship Orientation on SME's Business Performance: The Role of Entrepreneurial Marketing in Indonesian Batik Industries
}

\author{
Audita Nuvriasari $^{1} \quad$ Asmai Ishak $^{1} \quad$ Anas Hidayat $^{1} \quad$ Zainal Mustafa $^{1}$ Siswoyo Haryono ${ }^{2 *}$ \\ 1.Doctoral Program in Economics, Universitas Islam Indonesia Yogyakarta, Indonesia \\ 2.Doctoral Program in Management, Universitas Muhammadiyah Yogyakarta, Indonesia
}

\begin{abstract}
Although several researchers have studied entrepreneurial Marketing (EM), comprehensive testing of the EM integrative model has not been studied by previous researchers. Previous researchers were limited to examining the effect of antecedents on EM or business performance. The study is to discuss the influence of market and entrepreneurial orientation on the performance of SMEs. Entrepreneurial Marketing (EM) is a mediator. The sample is 285 managers of Batik SMEs in the Special Province of Yogyakarta and Central Java. Data were analyzed using Structural Equation Modelling (SEM) and to analyze the measurement models using the onecongeneric approach. The results of this study explain that market orientation and entrepreneurial orientation have a positive and significant effect on EM. Market orientation has an indirect effect on the performance of SMEs through EM as a mediator. Entrepreneurial orientation directly affects the performance of SMEs. The novelty in this study shows that EM plays an essential role in mediating market orientation and SME performance.
\end{abstract}

Keywords: market orientation, entrepreneurial orientation, entrepreneurial marketing, SMEs performance

DOI: $10.7176 / \mathrm{EJBM} / 12-5-04$

Publication date: February $29^{\text {th }} 2020$

\section{Introduction}

The era of globalization has pushed companies in developing countries to face increasingly fierce competition at different levels of competition. An increasingly competitive business environment encourages high levels of competition and can have a substantial impact on company performance (Al-Rfou, 2012). Company performance reflects how well a company is in achieving its goals. (Boachie-Mensah, 2015).

Company performance plays an essential role in business growth, where companies with excellent performance will be able to develop the business well and have business sustainability. The company's performance becomes a guideline for operating the business efficiently in order to achieve excellence and business sustainability (Na-nan, 2016). Business performance is central to strategic management, which has an essential role in measuring organizational effectiveness and as a tool to test the implementation of business strategies, which can be a basis for recommending performance improvement. Performance measurement is crucial for all companies because it helps in knowing the level of success or failure of all company activities (Trkman, 2010). Some studies have shown that company performance is influenced by (Chadamoyo, 2012); (Idris, 2015).

The study of company performance has been carried out by some researchers involving various variables as antecedents, one of which is market orientation. (Guleş, 2015)); (Al Mamun, 2018); (Udriyah, 2019)). Market orientation is a business orientation that defines marketing behavior or style within a company and illustrates how the company carries out its marketing functions. Market orientation is the most effective and efficient organizational culture for creating the behavior needed for the creation of superior value for consumers and superior performance for companies. Companies that implement market orientation will have an impact on improving performance. (Boohene, 2012).

In addition to market orientation, other antecedent variables that can affect company performance are entrepreneurial orientation (Hoque, 2019); (Taiwo, 2019). Internal factors that can also affect company performance are entrepreneurial orientation. Entrepreneurial orientation reflects the extent to which organizations can identify and exploit untapped opportunities. A company is said to have a spirit of entrepreneurial orientation if it can be the first to innovate new products in the market, have the courage to take risks, and always be proactive towards changing demands for new products. Some researchers explain that entrepreneurial-oriented companies can use 3 (three) strategic frameworks. These three frameworks become critical dimensions of entrepreneurial orientation, namely: innovativeness, risk-taking, and proactiveness (Taylor, 2013). Entrepreneurial-oriented companies tend to be more active in exploring new business opportunities caused by a proactive attitude, willingness to take risks, and innovative abilities (Kohtamäki, 2010).

Marketing approaches can also influence company performance in the form of entrepreneurial marketing or Entrepreneurial Marketing. (Hoque, 2019); (Dushi, 2019). In addition to organizational orientation factors in the form of market orientation and entrepreneurial orientation, other antecedents that can affect company performance are the entrepreneurial marketing approach. Entrepreneurial Marketing is an interface between marketing and 
entrepreneurship that emerges as marketing practices in companies that operate in highly dynamic environments (Ionită, 2012); (Sole, 2013). Entrepreneurial marketing can affect company outcomes, both qualitatively and quantitatively (Becherer, 2012). Some researchers prove that Entrepreneurship Marketing has a significant effect on company performance (Rasheed, 2016); (Hoque, 2019).

Some research results indicate a gap to research in the area of company performance by involving antecedent and mediating variables. To fill this gap, it encourages researchers to conduct further research by basing on an integrative model of Entrepreneurial Marketing (S. C. Morrish, 2011). The difference between current research and previous research shows a novelty. The novelty in this research is to comprehensively examine the integrative model of entrepreneurial marketing by placing market orientation and entrepreneurial orientation as antecedents of SME performance and placing entrepreneurship marketing as a mediator. Research examining the effect of antecedents on company performance with the role of mediating variables has been tested at various business scales, not only on large scale businesses but also on small and medium scale businesses. In this study, the object of research is Small and Medium Enterprises engaged in the batik industry, which operates in Java, especially in the Special Province of Yogyakarta and Central Java.

\section{Literature Review}

\section{Market Orientation}

Market orientation, $s$ one of the intangible organizational assets, especially those that are difficult for competitors to imitate these assets, create a competitive advantage that is sustainable and improves company performance (Lonial, 2015). Market orientation can e viewed from two perspectives, namely culture and behavior (BoachieMensah, 2015).

The level of ability of the company reflects market orientation, which connects to the external environment. This level of ability allows companies to compete to outperform their competitors through anticipating market needs and creating long-lasting relationships with customers, distributors, and suppliers. Market orientation is the ability and primary culture that is the principle of the organization. The main objective of market orientation is to deliver superior value for customers based on knowledge derived from customer and competitor analyses, where this knowledge is obtained and disseminated to all elements of the organization. Market orientation fosters a culture of experimentation and a focus on continuous improvement in company processes and systems. (Kumar, 2011)

Liao Chang mapped the involvement of market orientation with various variables such as antecedents, mediation, moderation, consequences based on the results of an orientation research survey. The domain variables involved with market orientation include: (a). Performance (business performance, brand performance, financial performance, new product performance, sales force performance), (b). Marketing functions (distribution channel collaboration, customer focus, international marketing, internal marketing, marketing concepts, marketing intelligence, marketing strategies, relationship marketing, supplier relations, and SCM), (c). Competition (alliance management, competitive environment, competitive power, competitive strategy, organizational change, organizational resources, RBV, resource management, SHRM), and (d). Quality (internal quality, service quality, TQM, market-oriented behavior, quality orientation). (Liao, 2011)

Market orientation is the most effective and efficient organizational culture in creating behavior that is important for the creation of superior value for consumers and will be a superior performance for business (Taleghani, 2013).

Hempenius explained that companies that show a more significant market orientation tend to use different marketing approaches. Companies with high market orientation have different market approaches which tend to implement more entrepreneurial marketing activities. Hempenius, in his research, stated that customer orientation in the form of customer service, product quality, and customer value had a positive effect on entrepreneurial marketing (Hempenius, 2012). Companies that actively involve customers in the marketing decision-making process determine products, prices, distribution, and marketing communications reflect that the company has implemented an entrepreneurial marketing approach in its marketing activities (S. C. Morrish, Miles, M.P., Deacon, J.H, 2010).

Based on the results of the study indicate that small-scale companies are generally less oriented towards competitors compared to large-scale companies (Mika, 2018). Competitor orientation is considered necessary for companies that implement entrepreneurial marketing, so competitor orientation must also be a concern in entrepreneurial marketing (Mika, 2018). Thus entrepreneurs play an essential role in understanding competition because in identifying opportunities in a changing environment. Small scale companies must pay more attention to direct and indirect competition in order to build sustainable competitive businesses and achieve superior business performance (O’Dwyer, 2017).

\section{Entrepreneurship Orientation}

Entrepreneurial orientation is a construct that shows the process of entrepreneurship and refers to the processes, practices, and decision-making styles and behaviors that drive to enter new markets or existing markets with new 
products/services or existing products/services (Kraus, 2009). The concept of entrepreneurial orientation refers to the level of processes, practices, decision-making styles, and corporate strategic orientation that helps companies to achieve competitive advantage and show superior performance (Kocak, 2017).

The entrepreneurial orientation, which consists of research and development, risk-taking, and proactive attitude, is one of the essential pillars in entrepreneurship marketing. Entrepreneurial oriented companies tend to use an entrepreneurial marketing approach (Jones, 2011). Companies with an increasingly entrepreneurial orientation will e expected to be more involved in entrepreneurial marketing behavior than companies with a lower entrepreneurial orientation level. Entrepreneurial orientation has a positive and significant influence on entrepreneurial marketing behavior in companies (Kilenthong, 2016). Hempenius, in his research, stated that entrepreneurial orientation, which consists of innovation and proactive attitude, has definite influence and has a strong relationship with entrepreneurial marketing. (Hempenius, 2012). This finding emphasizes that firms with higher entrepreneurial orientation more often use entrepreneurial marketing techniques. Outperform companies that are less involved in entrepreneurial orientation ability. Entrepreneurial orientation is a multidimensional construct that includes innovativeness, risk-taking, and proactiveness attitude (Fairoz, 2010); (Taylor, 2013).

The entrepreneurial literature does not have a consensus on how researchers must operate entrepreneurial orientation construction at the dimension level (Kilenthong, 2016). It is still debatable whether the entrepreneurial orientation seen as a unidimensional or multidimensional construct (Rauch, 2009). Some researchers view entrepreneurial orientation as unidimensional. Some researchers suggest that the dimensions of entrepreneurial orientation as multidimensional. Each dimension will describe the aspects of the multidimensional concept. Entrepreneurial orientation, as a multidimensional concept, can have different effects on company performance.

Several researchers suggest using the dimension of entrepreneurial orientation or, in other words, treating entrepreneurial orientation as a multidimensional concept. This suggestion would give different results, where each dimension in entrepreneurial orientation will show a different relationship with organizational performance. Thus the use of an entrepreneurial orientation dimension can make a unique contribution to all levels of company performance (Kreiser, 2013). Miller suggested that researchers do not always treat entrepreneurial orientation as a unidimensional construction. The researchers can treat it as a multidimensional construction because different dimensions of entrepreneurial orientation may have different relationships with the variables studied. (Miller, 2011)

Kilenthong's research results state that the level of innovation has a positive and significant influence on EM behavior in the company. The level of innovation is the dimension of entrepreneurial orientation that most strongly influences companies in the adoption of entrepreneurial marketing and is the core of entrepreneurial marketing behavior (Kilenthong, 2016)). The dimension of entrepreneurial orientation in the form of risk-taking in marketing defined as a willingness to use new methods that are considered unconventional without the guarantee that these actions will contribute positively to the company. Willingness to take risks is essential for Small and Medium Enterprises businesses because it will maximize the potential of the company, both products and services offered now or in the future (Kalsom, 2015). The degree of entrepreneurial inclination to take risks will substantially influence the type of marketing an organization will carry out. In a low risk-taking situation, there is a possibility that marketing activities will e kept to a minimum, and as a consequence, cannot exploit opportunities. On the other hand, in a high risk-taking situation, marketing activities tend to be expensive and inefficient (Gurău, 2012).

Risk-taking has a positive and significant influence on entrepreneurial marketing behavior in companies. Companies with higher levels of risk-taking have a significant influence on entrepreneurial marketing, especially on growth orientation and opportunity orientation. (Kilenthong, 2016). Companies with higher levels of risk-taking will use more networks and alliances in value creation. A proactive attitude as one of the dimensions of entrepreneurial orientation has a positive and significant influence on the adoption of entrepreneurial marketing in companies. More proactive companies will be more oriented towards opportunities and growth compared to less proactive companies. (Kilenthong, 2016).

\section{Entrepreneurship Marketing}

Entrepreneurial marketing is a behavior, a process that creates, communicates, and delivers value and in uncertain business environment conditions (Ionită, 2012). In its implementation, entrepreneurial marketing requires a market orientation approach and entrepreneurial orientation in the corporate strategy approach. By positioning the market orientation and entrepreneurial orientation in a balanced and complementary manner, it will encourage the achievement of higher business performance (S. C. Morrish, 2011).

The concept of entrepreneurial marketing can be using traditional marketing concepts and understanding. However, this understanding will never be complete without involving aspects of entrepreneurial theory, so entrepreneurial marketing is an interface between marketing and entrepreneurship (Hills, 2011).

Entrepreneurial marketing is a combination of innovative, proactive, and risk-taking activities that create, communicate and deliver value to and by customers, business people, marketers, partners, and society at large (Whalen, 2015).

Becherer proves that entrepreneurial marketing has a positive effect on outcomes of Small and Medium 
Enterprises, both qualitative and quantitative. The dominant dimension of value creation is an aspect of entrepreneurial marketing that influences not only financial performance but also non-financial performance. (Becherer, 2012). Entrepreneurial marketing has a direct influence on the competitiveness of Small and Medium Enterprises (Septiani, 2013). Suardhika explained that success in increasing competitive advantage in Small and Medium Enterprises is directly affected by entrepreneurial marketing and indirectly influenced by product innovation. (Suardhika, 2016). Hacioglu, in his research, explained that the dimensions of entrepreneurial marketing in the form of a proactive attitude, the level of innovation, customer intensity, and resource utilization significantly influence innovation performance. (Hacioglu, 2012). While the dimensions of entrepreneurial marketing in the form of a focus on opportunities, risk-taking, and value creation do not affect innovation performance. Al-Manasra proved that there is a strong relationship between entrepreneurial marketing and company performance (Al-Manasra, 2013). Entrepreneurial marketing has a positive and significant effect on the performance of Small and Medium Enterprises. (Rasheed, 2016); (Hoque, 2019). Entrepreneurial marketing has a significant effect on the non-financial performance of Small and Medium Enterprises but does not have a significant effect on the financial performance of Small and Medium Enterprises (Hempenius, 2012).

\section{Company performance}

Performance is a company's ability to produce output (Chittithaworn, 2011). Company performance is a multidimensional construct that does not merely include financial performance (Liao, 2011). Company performance is a measure of how well the organization or entity achieves its objectives (Boachie-Mensah, 2015). The performance is the ability to assess the level of success of a business organization both on a small and large scale. Small and Medium Enterprises can be in terms of employment levels, company size, capital strength, and profitability. (Olusola, 2011).

In general, it is difficult to determine a single measure for company performance. Measurement of company performance can be en as two perspectives, namely objective and subjective (Boachie-Mensah, 2015). It measures the performance of Small and Medium Enterprises with an objective approach measured through economic performance or financial performance, such as ROI, profit, sales, revenue growth, market share (Taleghani, 2013); (Dublhlela, 2014). Measurement of SME performance with a subjective approach s measured through noneconomic performance or non-financial performance, such as marketing performance, organizational performance, and operational performance (Taleghani, 2013).

\section{Hypothesis}

H1: Market orientation has a positive effect on entrepreneurial marketing

$\mathrm{H} 2$ : Entrepreneurial orientation has a positive effect on entrepreneurial marketing

H3: Market orientation has a positive effect on the SMEs performance

H4: Entrepreneurial orientation has a positive effect on the SMEs performance

H5: Entrepreneurial marketing has a positive effect on SMEs performance

\section{Research Design}

The research design used in this study uses quantitative research methods with associative problem formulation. Quantitative research methods based on the philosophy of positivism, used to examine populations or individual samples, sampling techniques are random, data collection using research instruments, quantitative or statistical data analysis testing the hypotheses (Haryono, 2017).

\section{Population and Research Samples}

This research applies quantitative research by developing valid and reliable research instruments. The total respondents were 285 leaders or responsible SMEs of various batik crafts in DIY Province and Central Java Province. Data collection through questionnaire distribution with the face-to-face method between respondents and researchers.

\section{Variable Operations}

In this study, there are three groups of research variables, namely: independent variables, mediating variables, and dependent variables. The independent variable consists of 2, namely: market orientation and entrepreneurial orientation. While the mediating variable is EM, and the dependent variable is the performance of SMEs. Measurement of research construction using instruments with a scale of 1-5 Likert. The scale represents ratings from 'strongly disagree' to 'strongly agree.'

\section{Research Analysis}

Two hundred eighty-five respondents filled out and returned the questionnaire. Analysis of research using the Structural Equation Modeling (SEM) method with Lisrel version 8.8. The first step of this analysis is the 
measurement of constructs to test the validity of the indicators that make up the construct. The instrument validity assessment uses the Confirmatory Factor Analysis (CFA). CFA will confirm a significant relationship between constructs and indicators based on the theory developed.

\section{DISCUSSION OF RESEARCH RESULTS}

Goodness of fit (GOF) test results on the final model confirm that all GOF coefficients are significant. Goodness of fit test results are: $\chi^{2}=0.00, \mathrm{CFI}=1.00, \mathrm{NFI}=1.00, \mathrm{GFI}=1.00$, and RMSEA $=0.00$. These results meet the required GOF cut-off value. Therefore, this research model is important in analyzing and testing the proposed hypothesis.

Figure 1 shows a model fit diagram from a study that summarizes the coefficients of the $t$ value. Meanwhile, Table 1 shows the standard path coefficients and t-values based on the final fit model.

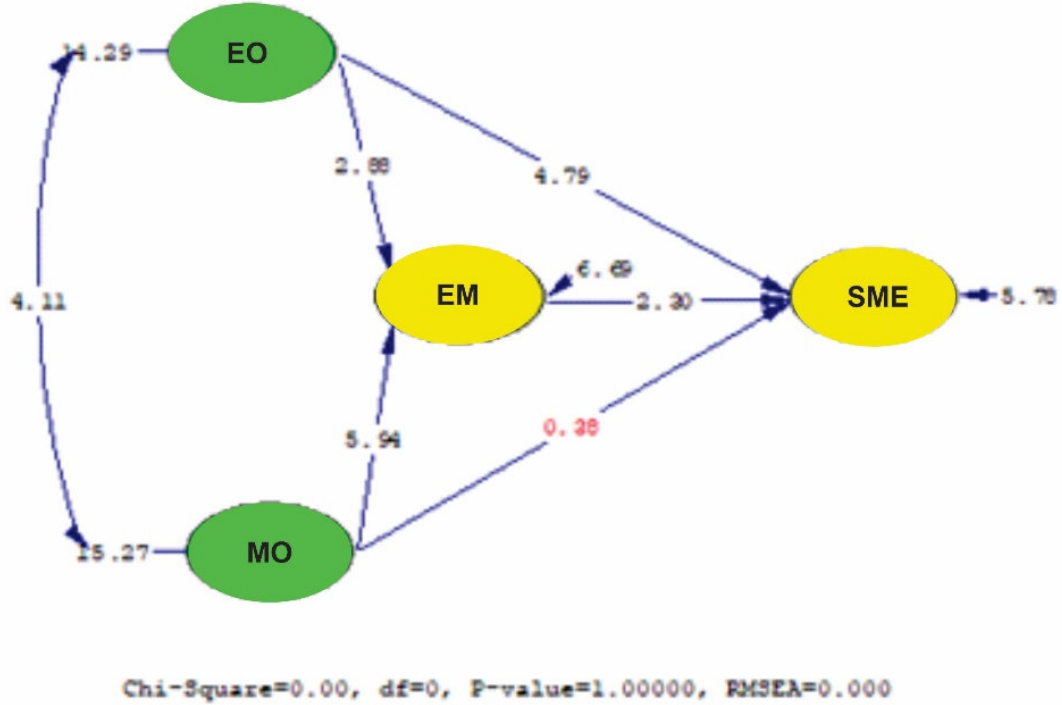

Figure 1. Diagram of model fit from the study: regression coefficient of $t$ value.

Table 1. Standard Path coefficients and t-values based on model fit.

\begin{tabular}{|l|c|c|c|c|c|}
\hline \multicolumn{1}{|c|}{ Regression Pathway } & $\begin{array}{c}\text { Coefficient } \\
\text { Regression }\end{array}$ & $\begin{array}{c}\text { Standard } \\
\text { Error }\end{array}$ & t-value & Prob. & Information \\
\hline $\begin{array}{l}\text { Market Orientation } \rightarrow \\
\text { Entrepreneurial Marketing }\end{array}$ & 0.29 & 0.05 & 5.94 & 0.0001 & Significant \\
\hline $\begin{array}{l}\text { Entrepreneurship Orientation } \rightarrow \\
\text { Entrepreneurial Marketing }\end{array}$ & 0.17 & 0.06 & 2.88 & 0.0043 & Significant \\
\hline $\begin{array}{l}\text { Market Orientation } \rightarrow \text { Kinerja } \\
\text { UKM }\end{array}$ & 0.02 & 0.06 & 0.38 & 0.7042 & $\begin{array}{c}\text { Not } \\
\text { Significant }\end{array}$ \\
\hline $\begin{array}{l}\text { Entrepreneurship Orientation } \rightarrow \\
\text { SMEs performance }\end{array}$ & 0.33 & 0.07 & 4.79 & 0.0001 & Significant \\
\hline $\begin{array}{l}\text { Entrepreneurial Marketing } \rightarrow \\
\text { SMEs performance }\end{array}$ & 0.24 & 0.11 & 2.30 & 0.0222 & Significant \\
\hline
\end{tabular}

\section{Effect of Market Orientation on Entrepreneurial Marketing}

Hypothesis 1 test results show that the value of $t$ is $5.94(\geq 1.96)$. This finding says that there is a positive and significant effect on market orientation towards Entrepreneurial Marketing. The results of this study are consistent with the integrative model of entrepreneurial marketing proposed by (S. C. Morrish, 2011), where market orientation as one of the internal environmental factors of an organization can influence companies in adopting an entrepreneurial marketing approach. Becherer and Helms explain that an organization's internal resources will influence the adoption of entrepreneurial marketing in companies. (Becherer, 2012). The results of this study are also in line with the EMICO (Entrepreneurial-Market-Innovation-Customer Orientation) framework proposed by (Jones 2011). Market orientation is one of the essential pillars of Entrepreneurial Marketing. The results of this study are consistent with research conducted by (Hempenius, 2012) which states that companies that have a high level of market orientation tend to use the entrepreneurial marketing approach in their business activities.

The Effect of Entrepreneurship Orientation on Entrepreneurial Marketing

Hypothesis 2 test results show that the value of $t$ is $2.88(\geq 1.96)$. This finding says that there is a positive and 
significant effect on entrepreneurial orientation on entrepreneurial marketing. The results of this study also provide support for empirical evidence on the integrative model of entrepreneurial marketing proposed by (S. C. Morrish, 2011), which states that entrepreneurial orientation as a factor in the organization's internal environment can influence companies in adopting an entrepreneurial marketing approach. The results of this study also strengthen the EMICO (Entrepreneurial-Market-Innovation-Customer Orientation) framework proposed by (Jones, 2011) which states that entrepreneurial orientation in the form of research and development activities, risk-taking and proactive attitudes is one of the essential pillars of marketing entrepreneurship. Innovation is an internal company factor that influences entrepreneurial marketing activities in Small and Medium Enterprises. (Habibzadeh, 2016). The higher the level of innovation in the company, the more influential for companies in practicing entrepreneurial marketing, and vice versa, if the level of innovation in a company is still low, the company is weak in practicing entrepreneurial marketing (Kilenthong, 2016). The results of this study are consistent with research conducted by Hempenius and Kilenthong, which explains that entrepreneurial orientation has a positive and significant effect on entrepreneurial marketing. Companies that have a high entrepreneurial orientation tend to use an entrepreneurial marketing approach in their business activities. (Hempenius, 2012); (Kilenthong, 2016).

\section{Effect of Market Orientation on the SMEs performance}

Hypothesis 3 test results show that the value of $t$ is $0.38(\leq 1.96)$. This finding says that there is no effect of market orientation on SME's performance. The results of this study support the results of previous studies, which stated that market orientation does not affect SME's performance (Haryanto, 2017); (Jeong, 2014). Pardi, in his research, explained that market orientation did not affect the performance of batik SMEs performance due to limited funding so that SMEs performance preferred production based on orders and lack of innovation in developing batik motifs. (Pardi, 2014). Market orientation does not affect the SME's performance in Indonesia is in line with research by Haryanto (2017). This result shows that business actors need more significant efforts to respond to customer demand, respond to the movements of competitors, and need to intensify coordination between functions in the company. Market orientation in SME's performance does not affect improving business performance. This finding is due to several factors, such as most SME's performance do not yet have a market-oriented culture. There are some factors in market-oriented culture: low motivation to win the competition, less modest products, low innovation, products are not consumers preference oriented, and depend on the role of government.

\section{The Effect of Entrepreneurship Orientation on the SMEs performance}

Hypothesis 4 test results show that the value of $t$ is 4.79 ( $\geq 1.96)$. This finding says that there is no effect of entrepreneurial orientation on the SME's performance. Innovation-oriented activities can affect the SME's performance, meaning that the higher the level of innovation undertaken by SMEs performance will further encourage the improvement of the SME's performance. This finding is consistent with several previous studies showing that the level of innovation has a positive and significant effect on company performance (Jalali, 2014); (Mason, 2015). This finding says that there is a positive and significant effect on entrepreneurial orientation on SME's performance. The results of this study support previous research, which states that entrepreneurial orientation has a positive and significant effect on company performance (Keh, 2007); (Taiwo, 2019). Entrepreneurial orientation is the key to the success of a company, where companies that are more entrepreneurial oriented will have better performance than those who are not entrepreneurial oriented. (Taylor, 2013).

\section{The Effect of Entrepreneurial Marketing on the SMEs performance}

Hypothesis 5 test results show that the value of $t$ is $2.30(\geq 1.96)$. This finding says that there is an effect of entrepreneurial marketing on SME's performance. The entrepreneurial marketing approach is the most appropriate strategy for SME's performance to improve business performance (Hoque, 2019). Entrepreneurial marketing internally plays a role in achieving the success of company goals such as profitability, increasing sales volume, and expanding the company's reach (Kalsom, 2015). The results of this study are consistent with the results of previous studies, which stated that entrepreneurial marketing has a positive and significant effect on company performance (Rasheed, 2016); (Hoque, 2019).

\section{CONCLUSION AND SUGGESTION}

Based on the discussion of research results, the conclusion that the better the implementation of market orientation in SMEs performance, the more encouraging the adoption of entrepreneurial marketing in SMEs performance. This finding because the existence of customer-oriented marketing activities and proper coordination between functions will affect SME's performance in implementing entrepreneurial marketing. The better the implementation of entrepreneurial orientation in SMEs performance, the more encouraging the adoption of entrepreneurial marketing in SMEs performance. This finding is because the willingness to innovate and courage in taking business risks will encourage Small and Medium Enterprises to implement entrepreneurial marketing. Market orientation does not affect the SME's performance due to several factors. The factors are: the dominant 
market served are businesses or organizations such as wholesalers or retailers, short-term customer orientation, inter-functional coordination is predominantly centralized on the leaders, the leadership weakness, and family business scale.

Entrepreneurial orientation affects SME's performance. Entrepreneurial-oriented SMEs tend to develop innovation, especially in product innovation and the willingness to take risks in running a business. With a strong entrepreneurial orientation, it can encourage improvement in SMEs performance. The results of this study also concluded that entrepreneurial marketing could mediate market orientation towards SME's performance. By implementing entrepreneurial marketing, businesses can proactively approach the market by directing consumers through innovation and customer focus. The entrepreneurial marketing approach can utilize collaboration with business partners so that it can support marketing activities. However, entrepreneurial marketing is not able to be a mediation between entrepreneurial orientation and the performance of SMEs. Entrepreneurship oriented SMEs have put forward innovation and creativity in their businesses to increase market interest and have an impact on improving performance.

\section{Suggestion}

First, this research model provides an overview of the role of market orientation and entrepreneurial orientation in building SME's performance. For this reason, the leadership of SMEs needs to build a market-oriented and entrepreneurial spirit. Inculcation of a culture of an organization oriented to customers and competitors as well as promoting coordination, cooperation, and communication between employees and between departments in the company in order to create superior value for customers can develop market orientation. Entrepreneurial-oriented organizational culture can be developed by increasing motivation in entrepreneurship by encouraging innovation, courage in taking business risks, and being proactive in developing businesses, taking advantage of opportunities, and facing existing and future competition.

Second, to improve the SME's performance, the leadership of SMEs needs to understand the marketing approach. The marketing activities in SMEs are often constrained by resources, relying more on creativity, simple marketing tactics, and using personal networks. SMEs marketing is necessary to use a marketing approach towards innovation and a proactive approach, practicing entrepreneurial marketing or entrepreneurial marketing approaches. With an entrepreneurial marketing approach, leaders in carrying out their business activities will focus on customers, develop partnerships with business partners to encourage product marketing, conduct free market analysis as one of the bases in marketing decision making and utilize proximity to markets (such as consumers and suppliers) to obtain market information.

Third, to encourage the improvement of the SMEs' performance, it is necessary to increase the competence of Human Resources through training, education, and human resource development activities. Innovation culture must continue to be developed not only on product innovation but also on process innovation, marketing, and organizational innovation. Partnership strategies with several parties such as suppliers, distributors, fellow business actors, and government and private institutions must continue so that it will facilitate the Small and Medium Enterprises in developing their businesses.

\section{References}

Al-Manasra, A., Al-Zyadat, M.A., Al-Awamreh, M.A., Alnsour, M.S. (2013). Linking Entrepreneurial Marketing and Performance Indicators in Jordanian Hotel Industry. Journal of Management Research, 5(3), 9.

Al-Rfou, A. N. (2012). Competition and Organizational Performance: Empirical Evidence from Jordanian Firms. J. Economics, 3(1), 5.

Al Mamun, A., Mohiuddin, M., Fazal, S.A., Ahmad, G.B.. (2018). Effect of Entrepreneurial and Market Orientation on Consumer Engagement and Performance of Manufacturing SMEs. Management Research Review, 41(1), 15.

Becherer, R. C., Helms, M.M., McDonald, J.P. (2012). The Effect of Entrepreneurial Marketing on Outcome Goals in SMEs. Journal of Entrepreneurship, 15(91), 17.

Boachie-Mensah, F., dan Issau, K. (2015). Market Orientation and the Performance of Small Medium-Sized Manufacturing Enterprises in the Accra Metropolis. International Journal of Marketing Studies, 7(3), 14.

Boohene, R., Agyapong, D., Asomaning, R. (2012). A Micro-Level Analysis of the Market Orientation - Small Business Financial Performance Nexus. American International Journal of Contemporary Research, $2(1), 12$.

Chadamoyo, P., Dumbu, E. (2012). Competitive Strategy and Business Environment Influencing Performance of Small and Medium Entreprises in the Manufacturing Sector: The Case Study of Manufacturing Firms in the Mucheke Light Industry. European Journal of Business And Management, 4(10), 8.

Chittithaworn, C., Islam, M.A., Yusuf, D.H.M. (2011). Factors Affecting Business Success of Small \& Medium Enterprises (SMEs) in Thailand. Asian Journal of Social Science, 7(5), 10.

Dublhlela, D. (2014). Modeling the Effects of Market Orientation Enablers on Business Performace among SMEs in a Developing Country. Mediterranean Journal of Social Sciences, 5(16), 9. 
Dushi, N. S., Dana, L.P., Ramadani, V. (2019). Entrepreneurial Marketing Dimensions and SMES Performance. Journal of Business Research, 100, 19.

Fairoz, F. M., Hirobumi, T., Tanaka, Y. (2010). Entrepreneurial Orientation and Business Performance of Small and Medium Sales Enterprises of Hambantota District Sri Lanka. Asian Social Science, 6(3), 13.

Guleş, H. K., Zerenler, M., Cagliyan, V., Sener, T, Karaboga, K. (2015). The Effect of Market Orientation and Innovation Ability on Enterprise Performance: A Practice of Structural Equation Modelling Analysis: A Research on SMEs. European Scientific Journal, 1, 12.

Gurău, C. (2012). Entrepreneurial Marketing: specificities, Challenges, and Opportunities. Paper presented at the International Conference "Marketing - from Information to Decision" 5th Edition.

Habibzadeh, M., Mestikani, F.A., dan Shoshtari, A.H. (2016). Identifying and Ranking the Factors Affecting Entrepreneurial Marketing to Facilitate Exports. Management Science Letters, 6, 7.

Hacioglu, G., Eren, S.S., Eren, M.S., Celikkan, H. (2012). The Effect of Entrepreneurial Marketing on Firms' Innovative Performance in Turkish SMEs. Social and Behavioral Sciences, 58, 8.

Haryanto, A. T., Haryono, T., Sawitri, H.S.R. (2017). Market Orientation, Learning Orientation and Small Medium Enterprises Performance: The Mediating Role of Innovation. International Review of Management and Marketing, 7(1), 8.

Hempenius, S. (2012). Entrepreneurial Marketing: Effects on Performance of SMEs. Thesis: Rotterdam School of Management. Erasmus University.

Hills, G. E., Hultman, C.M. (2011). Academic Roots: The Past and Present of Entrepreneurial Marketing. Journal of Small Business and Entrepreneurship, 24(1), 10.

Hoque, A. S. M. M., Awan, Z., Gwadabe, U.M. (2019). The Effect of Entrepreneurial Marketing on Bangladeshi SME Performance and The Role of Organizational Culture: A Structural Equation Modelling. Journal of Management and Operational Research, 1(16), 21.

Idris, S., Primiana, I. (2015). Effect of Competitive Strategy and Partnership. International Journal of Economics Commerce and Management, 3(4), 18.

Ionită, D. (2012). Entrepreneurial Marketing: A New Approach for Challenging Times. Management \& Marketing Challenges for the Knowledge Society, 7(1), 25.

Jalali, A., Jaafar, M., Ramayah, T. (2014). Entrepreneurial Orientation and Performance: The Interaction Effect of Customer Capital. World Journal of Entrepreneurship. Management and Sustainable Development, 10(1), 23.

Jeong, D. Y., Min, Kim, S., Ju, Yoon, D. (2014). Customer Orientation and Organizational Performance: A Mediating Role of CRM. Advanced Science and Technology Letters, 5(7), 5.

Jones, R., Rowley, J. (2011). Entrepreneurial Marketing in Small Business: A Conceptual Exploration. International Small Business Journal, 29(1), 12.

Kalsom, A. W., Rahim, A.B. (2015). The Understanding of Small Firm Performance and the Influence of Entrepreneurial Marketing on SMEs in Malaysia. Journal of Creative Writing, 1(3), 13.

Keh, H. T., Nguyen, T.T.M, Ng, H.W. (2007). The Effects of Entrepreneurial Orientation and Marketing Information on The Performance of SMEs. Journal of Business Venturing, 22(4), 20.

Kilenthong, P., Hultman, C.M., Hills, G.E. (2016). Entrepreneurial Marketing Behaviours: Impact of Firm Age, Firm Size, and Firm's Founder. Journal of Research in Marketing and Entrepreneurship, 18(1), 19.

Kocak, A., Carsrud, A. Oflazoglu, S. (2017). Market Entrepreneurial and Technology Orientations: Impact on Innovation and Firm Performance. Management Decision, 55(2), 23.

Kohtamäki, M., Kautonen, T., Kraus, S. (2010). Small Firm Performance: An Examination of the Role of Ambidexterity, Strategic Planning, and Entrepreneurial Orientation. International Journal of Entrepreneurship and Innovation, 9(3), 10.

Kraus, S., Harms, R., Fink. (2009). Entrepreneurial Marketing: Moving Beyond Marketing in New Ventures. International Journal Entrepreneurship and Innovation Management(special), 20.

Kreiser, P. M., Marino, L.D., Kuratko, D.F., Weaver, K.M. (2013). Disaggregating Entrepreneurial Orientation: The Non-Linear Impact of Innovativeness, Proactiveness, and Risk-Taking on SME Performance. Small Business Economics, 40(2), 19.

Kumar, V., Jones, E., Venkatesan, R., Leone, R.P. (2011). Is Market Orientation A Source of Sustainable Competitive Advantage or Simply The Cost of Competing? Journal of Marketing, 75(1), 15.

Liao, S. H., Chang, W.J., Wu, C.C., Katrichis, J.M. (2011). A Survey of Market Orientation research (1995-2008). Industrial Marketing Management, 40(2), 10.

Lonial, S. C., Carter, R.E. (2015). The Impact of Organizational Orientations on Medium and Small Firm Performance: A Resource-Based Perspective. 53(1), 20.

Mason, M. C., Floreani, J., Miani, S., Beltrame, F., Cappelletto, R. (2015). Understanding the Impact of Entrepreneurial Orientation in SMEs Performance: The Role of The Financing Structure. Procedia Economics and Finance, 13. 
Mika, W., Leminen, S. (2018). Does Entrepreneurial Marketing Underrate Competition? Technology Innovation Management Review, 8(9), 12.

Miller, D. (2011). Miller (1983) Revisited: A Reflection on EO Research and Some Suggestions for The Future. Entrepreneurship Theory and Practice, 35(5), 22.

Morrish, S. C. (2011). Entrepreneurial Marketing: A Strategy For The Twenty-First Century?. Journal of Research in Marketing and Entrepreneurship, 13(2), 10.

Morrish, S. C., Miles, M.P., Deacon, J.H. (2010). Entrepreneurial Marketing: Acknowledging the Entrepreneur and Customer-Centric Interrelationship. Journal of Strategic Marketing, 18(4), 14.

Na-nan, K. (2016). Performance Management for Small and Medium Enterprises (SMEs) in Thailand. International Journal of Economic Research, 13(4), 18.

O’Dwyer, M., Gilmore, A. (2017). Competitor Orientation in Successful SMEs: An Exploration of the Impact of Innovation. Journal of Strategic Marketing, 17.

Olusola, O. A. (2011). Accounting Skills as a Performance Factor for Small Business in Nigeria. Journal of Emerging Trends in Economics and Management Science, 2(5), 7.

Pardi, S., Imam. S., Zainul, A. (2014). The Effect of Market Orientation and Entrepreneurial Orientation toward Learning Orientation, Innovation, Competitive Advantage, and Marketing Performance. European Journal of Business And Management, 6(21), 7.

Rasheed, K. P., Gbenga, O., Aduragbemi, C. (2016). Entrepreneurial Marketing and SMEs Performance in Lagos State, Nigeria. Imperial journal Inquiry of Interdisciplinary Research, $2(1), 5$.

Rauch, A., Wiklund, J., Lumpkin, G.T., Frase, M. (2009). Entrepreneurial Orientation and Business Performance: An Assessment of Past Research and Suggestions. Entrepreneurship Theory and Practice, 33(3), 27.

Septiani, S., Sarma, M., Limbong, W.H. (2013). Pengaruh Entrepreneurial Marketing Dan Kebijakan Pemerintah Terhadap Daya Saing Industri Alas Kaki Di Bogor. Jurnal Manajemen dan Organisasi, 4(2), 21.

Sole, M. (2013). Entrepreneurial Marketing: Conceptual Exploration and Link to Performance. Journal of Research in Marketing and Entrepreneurship, 15(1), 16.

Suardhika, I. N., Suryani, N.K. (2016). Strategic Role of Entrepreneurial Marketing and Customer Relation Marketing To Improve Competitive Advantage in Small and Medium Enterprises in Bali, Indonesia. International Journal of Management and Commerce Innovations, 4(1), 10.

Taiwo, A., Adesoga, A., Olalekan, A. (2019). Effect of Entrepreneurial Orientation on Performance of Selected Small and Medium Scale Enterprises in Ogun State Nigeria. International Journal of Business and Management Invention (IJBMI), 8(1), 12.

Taleghani, M., S. Gilaninia, S.M. Talab. (2013). Relationship between Market Orientation Culture and Business Performance. Interdisciplinary Journal of Contemporary Research in Business, 5(1), 6.

Taylor, P. (2013). The Effect of Entrepreneurial Orientation on the Internationalization of SMEs in Developing Countries. African Journal of Business Management, 7(19), 11.

Trkman, P., McCormack, K. (2010). Supply Chain in Turbulent Environments - A Conceptual Model for Managing Supply Chain Network Risk. International Journal of Production Economics, 119(2), 12.

Udriyah, T., J., Azam, S.M.F. (2019). The Effects of Market Orientation and Innovation on Competitive Advantage and Business Performance of Textile SMEs. Management Science Letters, 9, 10.

Whalen, P. S., Akaka, M.A. (2015). A Dynamic Market Conceptualization for Entrepreneurial Marketing: The Co-Creation of Opportunities. Journal of Strategic Marketing, 15. 